Etnográfica

Revista do Centro em Rede de Investigação em

Antropologia

vol. $22(3) \mid 2018$

Vol. 22 (3)

\title{
Birthing matters in Portugal: introduction
}

A importância do parto em Portugal: introdução

\section{Anna Fedele and Joanna White}

\section{(2) OpenEdition}

\section{Journals}

\section{Electronic version}

URL: https://journals.openedition.org/etnografica/5951

DOI: 10.4000/etnografica.5951

ISSN: 2182-2891

\section{Publisher}

Centro em Rede de Investigação em Antropologia

\section{Printed version}

Date of publication: 1 October 2018

Number of pages: 607-618

ISSN: 0873-6561

Electronic reference

Anna Fedele and Joanna White, "Birthing matters in Portugal: introduction", Etnográfica [Online], vol. 22 (3) | 2018, Online since 10 October 2018, connection on 21 January 2022. URL: http://

journals.openedition.org/etnografica/5951; DOI: https://doi.org/10.4000/etnografica.5951

\section{(c) (i) (9)}

Etnográfica is licensed under a Creative Commons Attribution-NonCommercial 4.0 International License. 


\section{Birthing matters in Portugal: introduction}

\section{Anna Fedele and Joanna White}

In this introduction to the collection "Birthing matters in Portugal," the contributions of anthropology to the understanding of childbirth as social practice are outlined. Portugal is a country with one of the highest rates of medical intervention in childbirth in Europe, and widespread and diverse opposition to current medicalised approaches to birthing care in Portugal are becoming increasingly visible, yet the "alternative" practice of homebirth exists in a legal void. The introduction provides a summary of the historical emergence of the current situation, which has scarcely been explored to date by social science scholars. This colelction of articles is an attempt to bridge the present gap in knowledge by showcasing new anthropological research from Portugal on pregnancy and childbirth, offering analyses of birth which go beyond generalising descriptions of the oppositional discourses of specific social actors (e.g. doctors, midwives, homebirthers), and instead analyse the various reflections, collaborations, contestations and contradictions, in particular situations and settings. The experiences of women are foregrounded. The contribution of each of the four papers in the collection is described.

KEYWORDS: childbirth, medicalization, anthropology, Portugal, homebirth, pregnancy.

A importância do parto em Portugal: introdução - Nesta introdução ao dossier "A importância do parto em Portugal" são apresentadas as contribuições da antropologia para a compreensão do parto como prática social. Portugal apresenta uma das taxas mais altas da Europa de intervenção médica no parto, e uma ampla e diversificada oposição às atuais abordagens medicalizadas do parto em Portugal está a tornar-se cada vez mais visível; no entanto, a prática "alternativa" do parto domiciliar existe num vazio legal. Esta introdução fornece um resumo histórico da forma como a situação atual surgiu, o que até agora praticamente não foi explorado nas ciências sociais. O dossiê é uma tentativa de colmatar a atual lacuna no conhecimento, apresentando novas pesquisas antropológicas sobre gravidez e parto em Portugal, as quais oferecem novas análises que vão além da descrição generalizada dos discursos de oposição de atores sociais específicos (por exemplo, médicos, parteiras, pessoas que experienciaram partos domiciliares) e, em vez disso, analisam as várias reflexões, colaborações, contestações e contradições que emergem em situações e contextos particulares e, em especial, pondo a experiência das mulheres em primeiro plano.

PALAVRAS-CHAVE: parto, medicalização, antropologia, Portugal, parto domiciliar, gravidez.

FEDELE, Anna (fedele.anna@gmail.com) - Centro em Rede de Investigação em Antropologia, ISCTE - Instituto Universitário de Lisboa (CRIA-IUL), Portugal.

WHITE, Joanna (jowhite67@yahoo.co.uk) - University of the West of England, UK. 
PORTUGAL CURRENTLY HAS THE SECOND HIGHEST REPORTED RATE OF medicalised birth in Europe, based on combined data of rates of caesarean section (C-section) and vaginal instrumental birth (EPP 2013, reporting data from 2010). ${ }^{1}$ Available data reveal, moreover, the C-section rate to be consistently amongst the highest in Europe (EPP 2013), and part of a concerning trend regarding increasing C-section rates worldwide (WHO 2015). Indeed, the World Health Organization (WHO) criticized the lack of standards for acceptable C-section rates in the country (WHO 2010). Episiotomy rates for vaginal birth stand at $72.9 \%$ (EPP 2013). Systematic national data on certain elements of medicalised birth, such as the use of epidural in vaginal birth, induction of labour, the invasive procedure of artificially rupturing the membranes (the toque) and other procedures, such as the Kristeller manoeuvre, are not systematically collected. However, the rates of these interventions, though variable amongst different professional teams and health institutions, are also reported to be high. ${ }^{2}$ Some of these procedures are extremely controversial and associated with negative outcomes. ${ }^{3}$

Widespread and diverse opposition to current, medicalised approaches to birthing care in Portugal has become increasingly visible. Women's negative experiences of medicalised approaches have prompted a movement for "humanizing" birth and empowering women, based on an adaptation of international approaches (Akrich et al. 2014; APDMGP 2015). The Portuguese Association for the Humanization of Childbirth (Associação Portuguesa pela Humanização do Parto - Humpar), active since 2005, and the more recently created Portuguese Association for the Rights of Women in Pregnancy and Childbirth (Associação Portuguesa pelos Direitos da Mulher na Gravidez e Parto - APDMGP) advocate new approaches to birthing more focused on women's needs and rights (White and Schouten 2014; Akrich et al. 2014; APDMGP

I We would like to thank CRIA and CIES for supporting the series of film screenings and discussions on birth which took place at the University Institute of Lisbon (Instituto Universitário de Lisboa, ISCTE-IUL) between September 2014 and March 2015. We are particularly grateful to Antónia Lima, Manuela Cunha, Mário Santos, Maria Schouten and Mafalda Melo Sousa for their support and collaboration. All of the research presented in this dossier was made possible by funding from the Portuguese Foundation for Science and Technology (FCT): that of Francesca de Luca through a doctoral grant (SFRH/BD/93020/2013), that of Joanna White and Filipa Queirós through support as part of the EU Marie Curie Welcome II Programme (Welcome II/1 19/CRIA/1007/2011) and a scholarship as invited scientist (Joanna White, SFRH/BCC/52703/2014), that of Elizabeth Challinor within the strategic plan of CRIA (UID/ANT/04038/2013), and that of Anna Fedele as part of the same strategic plan (UID/ ANT/04038/2013), and as part of her activities as a postdoctoral researcher (SFRH/BPD/47864/2008) and later as FCT researcher (IF/01063/2014).

2 Personal communications from medical professionals working in a range of hospital settings in Portugal.

3 In relation to the toque, see, for example, RCM (2012); in relation to the Kristeller manoeuvre, see, for example, Matsuo et al. (2009) and Fedele, this volume. 
2015). Moreover, the phenomenon whereby some women decide to bypass available health services and give birth at home can be understood as a reaction to and rejection of the birthing options available within existing health services. Midwife-led qualitative studies have critiqued the dominant mode of hospital birth and called for a more "respectful" approach (see, for example, Ramalho 2011) and there have also been health policy-maker and practitioner-led initiatives directly aimed at reducing medical intervention rates (OE/ APEO 2012; Ayres-de-Campos et al. 2015). Any consequent transformation in medical practice appears to be slow-moving, however.

The historical developments, discourses and institutional practices contributing to the present situation have scarcely been explored by social science scholars, nor have women's experiences of medicalised (or alternative) approaches to childbirth been scrutinized. This special issue is an attempt to bridge the present gap in knowledge by showcasing new anthropological research from Portugal on pregnancy and childbirth. It represents a first step that will hopefully encourage further ethnographic as well as inter-disciplinary research in this direction.

Anthropology has made important contributions to the understanding of the social practices associated with reproduction since the pioneering work of Margaret Mead in the early decades of the twentieth century (Mead 1930). Several decades later, Brigitte Jordan's seminal cross-cultural scholarship (1993 [1978]) not only highlighted the locally-specific shaping of the universal physiology of birth, but established childbirth as a legitimate area of ethnographic enquiry, giving rise to the "anthropology of birth," which has had an important impact on social science study and childbirth activism alike (Oakley 2016). One of Jordan's most crucial contributions was her delineation of "authoritative knowledge," whereby certain knowledge forms associated with birth are socially sanctioned and privileged and accepted as grounds for legitimate interference, with different actors engaged in their routine production and reproduction. While different forms of knowledge may co-exist in any particular domain, some may gain ascendance and greater legitimacy than others because they apparently explain the world better for the purposes at hand, or are associated with a stronger power base (Jordan 1993 [1978]). In many situations multiple - sometimes competing - forms of knowledge are present by virtue of the status, experience and background of different participants in the birthing process. In this context of competing discourses, those who espouse "alternative" systems can often be labelled as backward, ignorant, naive, troublemakers (Jordan 1989, 1992).

Subsequent scholarship has provided important new empirical and theoretical contributions, often applying cross-cultural comparisons to elucidate the mechanisms of power and authority associated with pregnancy and birthing, and the increasing application of technology (Jordan 1992; Davis-Floyd 
and Sargent 1997; Kornelsen 2005). Such analyses have consistently demonstrated how the management of birth in any given setting is indicative of core or normative values.

Women's reported experiences during pregnancy and birth, and the attributes of women's agency, have become the focus of more recent studies, informed by feminist perspectives. It has been shown, for example, how childbirth education courses during the ante-natal period can constitute both a legitimization of the authoritative knowledge associated with medicalised birthing practices, but also a forum for challenging the authority of biomedicine, as women share and valorise their experiential knowledge (Ketler 2000). Martin (2003) emphasised the role of an internalised sense of gender amongst women in the disciplining of their selves and bodies during birth, while Tanassi (2004) delineated the strategic value of women's agency and behaviour in institutionalised settings and its contribution to the lived reality of birth. Akrich and Pasveer (2004) covered new ground in their analysis of the complex forms of embodiment experienced by women in the birthing process.

All of this existing body of work is clearly relevant to every cultural setting, yet the anthropological study of pregnancy and childbirth in Portugal to date remains extremely limited. Published work has focused on the material culture of traditional homebirthing (Ribeiro 1990) and the social function of midwives in supporting women during the emotionally as well as physically intense moment of birth (Joaquim 1983). In Joaquim's text, based on research conducted in the early 1980s, pain emerges as an essential element of a woman's life (see also De Luca, this volume). Joaquim observed that experiencing the pain of birth has emerged as a sort of initiatory test (prova iniciática) which women must pass in order to become a mother. ${ }^{4}$ The relatively recent widespread emergence of the epidural anaesthetic to manage women's labour pain, an intervention widely used in Portugal, adds new complexity to (historical) discourses on pain, which have, up to now, been little explored by researchers (but see De Luca, and White and Queirós, this volume).

A recent two-country ethnographic study of both Portugal and England (White 2016) built upon scholarship on temporality and birth (McCourt 2009), examining the different ways in which women absorbed and resisted the institutionalised structuring of time imposed upon them during pregnancy and childbirth, while also concluding that less agency was evidenced amongst women in the Portuguese context. Fedele has analysed the experiences of what she describes as holistic mothers, women who choose alternative ways of birthing and mothering because they consider pregnancy, birth and early childhood as important moments for the spiritual and psychological development of

4 See also Joaquim (2006) for an analysis of motherhood in Portugal and a discussion of the public maternity health sector in Portugal. 
mother and child. Fedele has shown how holistic mothers challenge biomedical models of the body and ask for a more women-centred care in Portugal (Fedele 2016; Fedele and Pasche Guignard 2018). Within broader social science research, homebirth has been examined as social practice (Santos 2012).

As feminist scholars and mothers who have devoted some years to the anthropological study of childbirth in Portugal, we consider it vital that emerging academic work in this area enters the public domain to inform ongoing debates. The papers in this dossier are based on presentations at a symposium entitled "Pregnancy and childbirth reframed: anthropological perspectives from Portugal," which took place in June 2015 at the Centre for Research in Anthropology (CRIA) of the University Institute of Lisbon (Instituto Universitário de Lisboa, ISCTE-IUL). CRIA first facilitated academic and public debate on birthing in Portugal through the hosting of a Lisbon seminar in 2013 (White and Schouten 2014). At this event, the intense interest in the cultural, social and gendered meanings of discourses and practices related to childbirth, and the outcome for women of current, medicalised approaches became apparent. This interest was evident not only amongst social scientists, but also midwives, doulas and the wider public. ${ }^{5}$ The documentary film cycle on childbirth which CRIA and the Centre for Research and Studies in Sociology (CIES) of ISCTE-IUL co-hosted between September 2014 and March 2015 confirmed this interest. At post-screening discussions, academics, medical professionals and women debated and shared experiences, at what were often very "charged" events, particularly when, on occasion, Portuguese women recounted the traumatic impacts which medicalised birth had had upon them. In a more recent development, CIES-IUL hosted a multi-disciplinary international conference on childbirth, "From birth to health: towards sustainable childbirth," in September 2018 .

Through the work presented in the current collection of papers we endeavour to situate (or re-position) women in the centre of our deliberations on childbirth. A diverse range of narratives are presented in the various papers, revealing women's agency in myriad forms. Both the historical process of knowledge production and contemporarily situated "authoritative knowledge," which influence current discourses and behaviour, are delineated. The papers selected for this collection reveal how, in different circumstances, personal, spiritual and also medical professional rhetoric can influence and underpin women's thinking and behaviour in relation to their pregnancy and birthing; women's critical capacity emerges as a key theme in a number of the papers included. The collection includes examples of different childbirth practices and their com-

5 A doula is a person without medical specialisation who assists a woman and her close family before, during and after childbirth (regarding the role of doulas in Portugal, see also Fedele, in this volume). 
plexities. It further provides evidence of how women's decisions and actions which challenge prevailing convention, and can be understood as threatening the current balance of power, are frequently not supported, and in some cases are directly opposed. Such responses contravene the concept of women-centred care, in other words, women's right to be fully supported in making an informed and personal choice regarding their method of birthing, without feeling discriminated against or harshly judged; a concept which we fully endorse.

Francesca De Luca's article opens our collection because it traces the foundations of biomedical discourses and practices in Portugal, furthering understanding of the contemporary aspects of childbirth which are at the centre of the papers which follow. The author explores the pain of labour in childbirth from its first appearance in Portuguese obstetric literature between the mid$19^{\text {th }}$ and early $20^{\text {th }}$ century, through an analysis of biomedical and others texts. This historical approach allows us to observe the changing meanings attributed by biomedical discourse to the pain of labour and women's labouring bodies. Thanks to De Luca's fine-grained analysis, we can see how the political, emotional and gendered struggles to define and circumscribe the pain of labour are not only a contemporary phenomenon but represent an ongoing process. Debates and practices around pain oscillate between two extremes: on the one side, there are the biomedical efforts to eliminate pain, considering it as useless (see also White and Queirós, this volume), even cruel, a punishment given by the Judeo-Christian God to punish women for the fall of Eve (Pina-Cabral 1986); on the other side, "alternative" approaches to birth emphasise its positive contribution to physiological birth, and its potentially transformative and empowering effects for women. Common to all these discourses, however, is the quest for a positive experience of birth.

De Luca's paper alludes to how, in the historical Catholic reality of childbirth in Portugal, pain can be seen to have represented a specifically gendered means of expiating sin, in the context of what de Luca described as a life "vowed to sacrifice". This scenario radically changed with the development of anaesthetic practices during the $19^{\text {th }}$ century. Gradually, the elimination of pain became a moral duty for the Portuguese obstetricians who, following Hippocrates motto divinum est opus sedare dolorem, assumed a God-like role, employing different forms of anaesthesia. Pain thereby appeared as a "disembodied, ontological phenomenon" to be separated from the birthing process in a context in which the necessity of delivering women from suffering became the foundation of modern obstetrics in Portugal.

Focusing on the contrasting interpretations of childbirth amongst obstetricians and midwives in Portugal, Joanna White and Filipa Queirós demonstrate how the avoidance of pain through anaesthetic pain relief and/or procedures and methods of intervention in labour and birth to speed up the process still remain at the centre of the contemporary biomedical discourse largely shared 
by obstetricians. This approach contrasts with that of midwives, who generally focus their efforts on a minimization of medical intervention according to a model of "normal birth" in which women's choices are respected and supported (except in the case of clinical necessity). Here we encounter not only two distinct discourses on childbirth but also on the meaning of "progress". For obstetricians, progress is symbolised by the availability and logical application of medical technology. For many midwives, however, progress implies respecting women's choices while also promoting physiological birth as a desirable goal, with access to technical medical support for those women who desire or need it. Women who give birth in hospital will often be confronted with these two different philosophies of birth.

The tensions between obstetricians and midwives become immediately evident if we consider the names assigned to the professionals who assist women during birth. Even if some of them identify themselves as midwives (parteiras), they are not officially called midwives, but specialist nurses, thereby emphasising their subordinate role to doctors in the medical hierarchy. In fact, the role and responsibility of these individuals is not equivalent to that of midwives within other national health systems such as in the UK or the Netherlands, for instance. Little effort is made to enhance dialogue between these two groups through common meetings or clear rules about their cooperation. Midwives generally consider their work not only as complimentary to that of doctors, but equally essential. While doctors may also support this vision, the real tensions associated with the daily parallel work of the two professional groups in the hospital setting is elucidated in this paper. The authors, further, highlight the difficulties of conducting fieldwork in hospitals. Some doctors' reluctance to participate in social scientific studies poses a particular obstacle. Yet doctors' voices and perspectives are critical to ongoing debates concerning the future of childbirth in Portugal.

Elizabeth Challinor's auto-ethnographic article analyses the hospitalised birth of her third child in northern Portugal, after giving birth at home twice in the UK. The author provides a first-hand account of a woman's struggle to be able to have the birth she wants despite external pressures. Her post-event reflection on and locating of her personal experiences within the wider Portuguese social and cultural landscape of birthing is not only informative, but constitutes a meaningful reflection on the liberating and empowering effects of narrative creation as an act of agency at times when we feel we have little power.

One of the issues emerging from Challinor's account is the important role played by certain health professionals - both midwives and doctors -, "guardian angels," who try and support women's autonomy in birthing, and enable women in their care to subvert the dominant system. As White and Queirós suggest in their article in this issue, there exist "windows of care" through 
which women giving birth can receive quite varied forms of attention; in some cases, dedicated, respectful approaches can offer escape from the routinized medicalisation of birth in Portuguese hospitals.

In the final article of this dossier, Anna Fedele analyses what happens when women who embrace holistic mothering and choose to give birth at home end up in a hospital. Fedele reveals the influence that Robbie Davis-Floyd's analysis on birth as an American rite of passage in the US (Davis-Floyd 2003 [1992]) has on holistic mothers as well as on international movements for the humanisation of birth, and the problems related to a dichotomised conceptualisation of an alternative, "wholistic" model and a "technocratic" model predominating in contemporary hospitals. Fedele argues that the oppositional construction of these two models can lead to traumatic experiences for those mothers who choose homebirth but end up giving birth in a hospital. She argues that more research on issues of gender and power within the movement for the humanisation of birth is needed, not only in Portugal but also elsewhere. Fedele suggests that this kind of research should include long-term studies using qualitative analysis, participant observation and the elaboration of life histories in order to grasp the complex reality of birth and birthing traumas, in a way that takes into account also their religious and spiritual dimension.

Homebirth exists in a legal void in contemporary Portugal and is resisted by many health professionals who consider it a retrograde step. At least up to the 1960s, in Lisbon only a minority of births took place in hospital, and in the rural areas of Portugal homebirth still represented the most common scenario throughout the 1970s and into the 1980s, supported by the national health system. However, women who choose homebirth nowadays tend to be considered as irresponsible and gullible individuals who put themselves and their babies at risk. Their choices, further, are interpreted as posing a risk to the entire society, threatening the Portugal modernisation project (see also Fedele and Pasche Guignard 2018). In this scenario, homebirth is related to a distant, rural, even primitive past, as opposed to the kind of modern, progressive, European country which "the Portuguese" are understood to be striving for. Indeed, within this discourse, not only homebirth but other forms of birthing that are not conceived within the biomedical perspective of intervention to facilitate birth, such as those which seek to avoid anaesthesia, are similarly considered to be practices belonging to a rural and pre-modern Portugal (see also White and Queirós, this volume). Unlike in other European countries such as the Netherlands, Sweden or the UK, where women opting for homebirth are supported by the state as part of an ongoing collaboration between the midwives attending homebirth and hospitals, Portuguese women who choose homebirth are confronted with a lack of support for their choice and poor communication between the medical establishment and the exponents of the alternative care 
sector. It is this lack of institutional support and associated poor coordination which pervades homebirth with particular risk in the Portuguese setting.

The new research presented in this collection highlights the unique potential of ethnography and broader anthropological approaches in analysing and elaborating the complex cultural dynamics underpinning one of the most universal human events: that of giving birth. It is our hope that this collection demonstrates how a multi-layered anthropological approach can enhance understanding of childbirth not only in the Portuguese context but also internationally.

One of Brigitte Jordan's many contributions to the nascent anthropology of birth was to distinguish between the debate on what is deemed to be the "right" approach, and the scholarly analysis of what "counts" in a socio-cultural sense. This distinction emphasises the importance of analysing and understanding how participants in birth share different forms of knowledge with each other, ratify it, elaborate it, or in some cases, enforce it (Jordan 1989). In a worldwide scenario in which women in poor countries have no access to medical assistance should they require it, the demands of women in Western countries for a more humanized birth can, perhaps, be dismissed by some as the claims of privileged women who are not aware of the advantages they hold. This is particularly true in countries such as Portugal, where great efforts were made following the Salazar dictatorship to establish an effective public health system and hospital network. While we may have our own personal opinions and positions, however, our energies are firmly devoted to the academic exposition of socio-cultural dynamics, as reflected in this collection of papers. It is important to recall that Jordan advocated a seeking of commonality - a dialogic approach of mutual accommodation, proven to be successful in some settings (Jordan 1992). We are adherents to this approach. Ongoing dialogue and exchange between academics and the medical establishment, as well as with representatives of the public health care sector, are essential. Some strides have already been made by medical anthropology scholars in Portugal in this area (see, for instance, Pussetti and Brazzabeni 2011), and we support any new measures which pave the way for more fruitful future collaboration (though see White and Queirós in this issue regarding the continuing barriers to conducting social science research in hospital settings).

Joining the efforts of other social scientists to describe the complex identity and power struggles that inevitably surround an event that marks the entry of a new individual into society, the articles presented in this collection problematize dichotomies such as hospitalised birth/home birth, technocratic/ wholistic, passive/active birth. On an international level, this ethnographic work aims to contribute to ongoing efforts to offer new analyses of birth which go beyond generalising descriptions of the oppositional discourses of specific social actors (e.g. doctors, midwives, homebirthers), and instead analyse the 
various reflections, collaborations, contestations and contradictions which emerge in particular situations and settings. In our opinion, comprehensive analysis and understanding of birth is only possible through the inclusion of probing primary qualitative studies, including ethnography, as well as birth narratives, all of which attempt to capture the lived complexities of this deeply physical, emotional, personal and yet most socio-cultural event.

In the Portuguese context, this collection forms part of a growing and more visible body of university research activity; further new ethnographic work is underway at the Institute of Social Sciences (ICS-UL) in Lisbon examining the cultural understanding of pain in childbirth and of obstetric violence in Portugal, for example, while wider social science investigation at CIES-IUL is exploring the choice and meaning of homebirth, a practice which remains controversial in Portugal, despite being supported by the medical system in some European countries, and even promoted as a safer option for certain groups of women in the United Kingdom. ${ }^{6}$ We have also observed a striking level of interest in the study of birthing practices, experiences and outcomes among new post-graduate students. Clearly, childbirth is a subject which will not and should not go away, and we hope that this collection of papers will contribute to the promotion of this subject in Portugal as a matter of both scholarly and social importance.

\section{REFERENCES}

AKRICH, Madeleine, and Bernike PASVEER, 2004, "Embodiment and disembodiment in childbirth narratives", Body and Society, 10 (2-3): 63-84.

AKRICH, Madeleine, et al., 2014, "Practising childbirth activism: a politics of evidence", BioSocieties, 9 (2): 129-152.

APDMGP - ASSOCIAÇÃO PORTUGUESA PELOS DIREITOS DA MULHER NA GRAVIDEZ E NO PARTO, 2015, Experiências de Parto em Portugal: Inquérito às Mulheres sobre as Suas Experiências de Parto. Lisbon, APDMGP.

AYRES-DE-CAMPOS, Diogo, et al., 2015, "Lowered national cesarean section rates after a concerted action", Acta Obstetricia et Gynecologica Scandinavica, 94 (4): 391-398.

DAVIS-FLOYD, Robbie E., 2003 [1992], Birth as an American Rite of Passage. Berkeley and Los Angeles, University of California Press ( $2^{\text {nd }}$ edition).

DAVIS-FLOYD, Robbie E., and Carolyn F. SARGENT, 1997, Childbirth and Authoritative

6 See the Birthplace project: < https://www.npeu.ox.ac.uk/birthplace/results > (last access in October 2018). 
Knowledge: Cross-Cultural Perspectives. Berkeley, University of California Press.

EPP - EURO-PERISTAT PROJECT, with SCPE and Eurocat, 2013, European Perinatal Health Report: The Health and Care of Pregnant Women and Babies in Europe in 2010, available at < http://www.europeristat.com/images/European\%20Perinatal\%20Health\%20Report_2 010.pdf $>$ (last access in October 2018).

FEDELE, Anna, 2016, “'Holistic mothers' or 'bad mothers'? Challenging biomedical models of the body in Portugal”, Religion and Gender, 6 (1): 95-111.

FEDELE, Anna, and Florence PASCHE GUIGNARD, 2018, "Pushing from the margins: comparative perspectives on 'natural childbirth' in contemporary holistic spiritualities and natural parenting in France and Portugal", in M. de la Porte and M. Martin (eds.), Sacred Inception: Reclaiming the Spirituality of Birth in the Modern World. New York, Demeter Press, 131-150.

JOAQUIM, Teresa, 1983, Dar à Luz: Ensaio sobre as Práticas e Crenças da Gravidez, Parto e Pós-Parto em Portugal. Lisbon, Dom Quixote.

JOAQUIM, Teresa, 2006, Cuidar dos Outros, Cuidar de Si: Questões em Torno da Maternidade. Lisbon, Livros Horizonte.

JORDAN, Brigitte, 1989, "The ultimate failure: court-ordered Cesarean section: a case of differing realities", in L. Whiteford and M. Poland (eds.), New Approaches to Human Reproduction. Boulder, CO, Westview Press, 13-24.

JORDAN, Brigitte, 1992, "Authoritative knowledge and its construction: introductory remarks to symposium on 'Birth in twelve cultures: papers in honor of Brigitte Jordan'”, presented at the Annual Meeting of the American Anthropological Association, Xerox Palo Alto Research Center and Institute for Research on Learning, San Francisco, CA, December.

JORDAN, Brigitte, 1993 [1978], Birth in Four Cultures: A Crosscultural Investigation of Childbirth in Yucatan, Holland, Sweden, and the United States. Prospect Heights, IL, Waveland Press.

KETLER, Suzanne K., 2000, "Preparing for motherhood: authoritative knowledge and the undercurrents of shared experience in two childbirth education courses in Cagliari, Italy", Medical Anthropology Quarterly, 14 (2): 138-158.

KORNELSEN, Jude, 2005, "Essences and imperatives: An investigation of technology in childbirth”, Social Science \& Medicine, 61 (7): 1495-1504.

MARTIN, Karin A., 2003, "Giving birth like a girl”, Gender \& Society, 17 (1): 54-72.

MATSUO, Koji, et al., 2009, "Use of uterine fundal pressure maneuver at vaginal delivery and risk of severe perineal laceration”, Archives of Gynecology and Obstetrics, 280 (5): 781 $-786$.

McCOURT, Christine, 2009 (ed.), Childbirth, Midwifery and Concepts of Time. Oxford, Berghahn Books.

MEAD, Margaret, 1930, Growing Up in New Guinea. New York, Blue Ribbon.

OAKLEY, Anne, 2016, "The sociology of childbirth: an autobiographical journey through four decades of research", Sociology of Health and Illness, 38 (5): 689-705.

OE/APEO - ORDEM DOS ENFERMEIROS/ASSOCIAÇÃO PORTUGUESA DOS ENFERMEIROS OBStetras, 2012, Pelo Direito ao Parto Normal: Uma Visão Partilhada. Lisbon, OE/APEO, available at < https://www.ordemenfermeiros.pt/arquivo/publicacoes/Documents/Livro_ Parto_Normal.pdf $>$ (last access in October 2018).

PINA-CABRAL, João de, 1986, Sons of Adam, Daughters of Eve: The Peasant Worldview of the Alto 
Minho. Oxford, Clarendon Press.

PUSSETTI, Chiara, and Micol BRAZZABENI (eds.), 2011 , dossier "Vivenciar o sofrimento social: suas ambiguidades e articulações”, Etnográfica, 15 (3), 467-478.

RAMAlHO, Anabela, 201 1, Trabalho de Parto no Hospital: A Experiência de Sentir-se Respeitada. Coimbra, Formasau.

RCM - THE ROYAL COLLEGE OF MIDWIVES, 2012, Evidence Based Guidelines for Midwifery-Led Care in Labour: Rupturing Membranes. London, RCM.

RIBEIRO, Margarida, 1990, Temas de Etnologia: Maternidade. Lisbon, Livros Horizonte.

SANTOS, Mário João Duarte da Silva, 2012, Nascer em Casa: A Desinstitucionalização Reflexiva do Parto no Contexto Português. Lisbon, ISCTE-IUL, MA thesis in Health, Medicine and Society.

TANASSI, Lucia M., 2004, "Compliance as strategy: the importance of personalised relations in obstetric practice”, Social Science \& Medicine, 59: 2053-2069.

WHITE, Joanna, 2016, “'But isn't it the baby who decides when it will be born?': temporality and women's embodied experiences of giving birth”, Cambridge Journal of Anthropology, 34: 72-86.

WHITE, Joanna, and Maria Johanna SCHOUTEN, 2014, "Normal birth as a cultural phenomenon", in Joanna White and Maria Johanna Schouten (eds.), Normal Birth: Experiences from Portugal and Beyond/O Parto Normal: Experiências de Portugal e Além-Fronteiras. Braga, CICS, and Lisbon, CRIA, 13-20.

WHO - WORLD HEALTH ORGANIZATION, 2010, WHO Evaluation of the National Health Plan of Portugal (2004-2010). Copenhagen, World Health Organization Regional Office for Europe.

WHO - WORLD HEALTH ORGANIZATION, 2015, WHO Statement on Caesarean Section Rates. Geneva, World Health Organization Department of Reproductive Health and Research. 